\title{
Perkecambahan Benih Kopi Dengan Pemberian Konsentrasi Hormon Giberellin (GA3) dan Jenis Air yang Berbeda
}

\section{Germination Seed Coffee With Concentration Giberellin Hormone (GA3) and Different Water Types}

\author{
Dede Suhendra*, Siska Efendi, Aswaldi Anwar \\ Department of Agroecotechnology, Faculty of Agriculture, Andalas University, Padang, Indonesia \\ *Corresponding author. dedesuhendra@agr.unand.ac.id
}

Received: September 1, 2021; Accepted: September 23, 2021; Published: October 31, 2021

\begin{abstract}
The propagation plants coffee is carried out in generative manner and needs be optimized with treating gibberellin hormone and water temperature to germination stage of coffee seeds. The research conducted at the Seed Technology Laboratory Faculty Agiculture, Andalas University from May to August 2021. Measurement parameters were germination rate (days), normal germination (\%), abnormal germination (\%) and dead seeds (\%). The results showed that germination rate (days), normal germination (\%) and abnormal germination (\%) showed a significant effect. While the data had no significant effect on the observation of dead seeds (\%) in the treatment of gibberellin hormone concentration and treatment of water types, which in the observation of normal sprouts was the highest, namely in the treatment of $400 \mathrm{ppm}$ gibberellin hormone concentration with coconut water (G4J3) of $86.67 \%$ and on seed observation. The highest death rate was treatment gibberellin hormone $200 \mathrm{ppm}$ with mineral water temperature $60^{\circ} \mathrm{C}$ (G1J2) which was $33.33 \%$. Giberelin and mineral water can affect coffee germination.
\end{abstract}

Keywords: coconut water; dormantion; recalsitran

Cite this as: Suhendra, D., Effendi, S, \& Anwar, A. (2021). Perkecambahan Benih Kopi Dengan Pemberian Konsentrasi Hormon Giberellin (GA3) dan Jenis Air yang Berbeda. Agrosains : Jurnal Penelitian Agronomi, 23(2), 114-118. DOI: http://dx.doi.org/10.20961/agsjpa.v23i2.54780

\section{PENDAHULUAN}

Sumatera Barat merupakan salah satu daerah penghasil buah kopi di Indonesia. Perkebunan kopi di Sumatera Barat sejak tahun 2018 sampai 2020 memiliki luas areal yakni $31.621 \mathrm{Ha}$; $29.625 \mathrm{Ha}$; dan $29.646 \mathrm{Ha}$ dengan produksi 18.452 ton; 17.822 ton; dan 29.539 ton. Kopi di Sumatera Barat berkontribusi terhadap perekonomian Indonesia namun karena produksi kopi di Sumatera Barat masih rendah maka dilakukan percepatan pengembangan komoditi kopi melalui perluasan areal tanam dalam menghasilkan tanaman kopi, karena di daerah ini memiliki potensi dalam hal ketersediaan lahan yang luas dan kesesuaian lingkungan yang baik untuk melakukan budidaya tanaman kopi (BPS, 2020).

Pertumbuhan optimal tanaman kopi terkendala beberapa faktor yaitu bibit abnormal, percabangan ganda dan perakaran yang tidak berkembang, dengan kondisi tersebut. Pemeliharaan yang dilakukan seperti penggunaan media tanam yang tidak sesuai, intensitas cahaya tidak optimal dan penanaman bibit yang salah menyebabkan pertumbuhan bibit kopi tidak optimal (Netse \& Kufa, 2015). Jadi untuk perluasan areal didukung juga dengan kondisi ketersediaan bibit unggul yang berkualitas dan teknik pemeliharaan yang baik.

Bibit unggul merupakan modal keberhasilan pertumbuhan suatu tanaman di lapangan karena dapat berproduksi optimal. Pada dasarnya perbanyakan kopi umumnya secara generatif, kendala yang dialami pada perbanyakan kopi secara generatif adalah biji kopi memerlukan waktu cukup lama untuk berkecambah. Kondisi kulit biji keras berdampak pada air dan udara yang dibutuhkan dalam proses perkecambahan, sehingga tidak dapat terserap oleh biji akhirnya proses perkecambahan berlangsung dalam waktu lama (Lestari et al., 2016).

Kulit biji yang impermeabel juga berpengaruh menjadi mereduksi kandungan $\mathrm{O}_{2}$ dalam benih sehingga pada kondisi anaerobik terjadi sintesis zat penghambat tumbuh. Agar terbentuk stadium serdadu (hipokotil tegak lurus) dibutuhkan waktu 4-6 minggu, lalu untuk mencapai stadium kepelan (membukanya kotiledon) dibutuhkan waktu 8-12 minggu. Kondisi ini tentu akan berdampak pada penyediaan bibit tanaman kopi (Najiyati \& Danarti, 2012). Pertumbuhan bibit yang lambat dan tidak seragam berdampak pada proses perkecambahan benih yang kurang baik (Rosa et al., 2010).

Zat pengatur tumbuh yang dapat merespon perkecambahan dan pertumbuhan adalah hormon giberelin yang berperan dalam pengembangan dinding sel, pembesaran sel dan pembelahan sel. Giberelin berperan dalam fase berkecambah terjadi pembentukan enzim a-amilase pada kondisi lapisan aleuron, berpengaruh terjadinya perpanjangan ruas tanaman dengan bertambahnya jumlah dan besar sel-sel pada ruas-ruas tersebut (Andjarikmawati et al., 2005). Hal ini berdasarkan Hardiyanto (1995) yang dapat mengoptimalkan persentase dan kecepatan 
berkecambah pada benih manggis dan markisa dengan melakukan perendaman giberelin $50 \mathrm{ppm}$. Lalu penelitian sebelumnya Suhendra (2020) diperoleh dapat meningkatkan kecepatan tumbuh benih kopi dengan pemberian hormon giberelin 200 ppm.

Salah satu cara yang digunakan untuk pematahan dormansi benih adalah dilakukannya merendam benih dengan jenis air berbeda yakni air kelapa, aquadest dan air panas $60^{\circ} \mathrm{C}$. Perendaman benih dengan jenis air yang berbeda adalah untuk melihat jenis air yang efektif dalam mengatasi dormansi. Perendaman benih dengan jenis air yang berbeda dapat melunakkan lalu membuka poripori kulit benih yang keras. Menurut Marthen et al. (2013), benih sengon yang direndam dengan air panas $60^{\circ} \mathrm{C}$ memberikan hasil tertinggi pada persentase perkecambahan lalu laju perkecambahan sebesar $100 \%$ dan berpengaruh pada kondisi fisik benih yakni bobot dan kadar air benih.

Benih kopi disimpan pada jangka menengah diketahui bahwa benih tersebut bisa disimpan selama 10 bulan pada suhu $15^{\circ} \mathrm{C}$ pada kadar air 10 - $11 \%$. untuk produksi bibit kopi biasanya biji kopi tidak dikeringkan tetapi langsung disemai untuk dijadikan bibit. Biji kopi dipanen pada fase matang ceri, namun biji kopi memperoleh kapasitas perkecambahan maksimum ketika buah berada diantara warna hijau dan ceri (Rosa et al, 2011).

Berdasarkan permasalahan biji kopi yang susah berkecambah maka dilakukan pengujian dengan perlakuan hormon giberelin dan jenis air yang berbeda. Lalu berdasarkan penelitian sebelumnya menjadi landasan penulis dalam mencoba memberikan peningkatan taraf perlakuan hormon $\mathrm{GA}_{3}$ dan jenis air yang berbeda untuk melihat perkecambahan benih kopi. Penelitian ini bertujuan untuk mengetahui perkecambahan benih kopi terhadap perlakuan hormon $\mathrm{GA}_{3}$ dengan perendaman jenis air yang berbeda.

\section{BAHAN DAN METODE}

Penelitian ini dilakukan di Laboratorium Teknologi Benih Fakulltas Pertanian Universitas Andalas pada bulan Mei - Agustus 2021. Pelaksanaan penelitian ini digunakan bahan antara lain benih kopi robusta yang diambil di desa Payo kabupaten Solok Sumatera Barat, Pasir Steril, Hormon Giberelin, Alkohol 96\%, Akuades, Air Kelapa, Tissue, Kertas HVS dan Kertas Label. Alat yang digunakan dalam penelitian ini adalah seedbag, handsprayer, botol-botol plastik, timbangan analitik, beaker glass, oven, termometer, kamera, kompor, dan alat tulis.

Penelitian ini menggunakan Rancangan Acak Kelompok (RAK) 2 Faktor Perlakuan yakni:

Faktor I : Konsentrasi Hormon Giberelin (GA3) (G) yang terdiri oleh 4 Taraf yaitu :
G1 : 100 ppm
G2 : 200 ppm
G3 : 300 ppm
G4 : 400 ppm

Faktor II : Perendaman Dengan Jenis Air Berbeda (J) yang terdiri oleh 3 Taraf yaitu :
J1 : Aquadest
J2 : Air Mineral Suhu $60^{\circ} \mathrm{C}$
J3 : Air Kelapa

Data yang diperoleh untuk mengetahui ada tidaknya pengaruh perlakuan dan adanya interaksi perlakuan, diuji dengan analisis ragam pada taraf 5\%. Untuk pengujian lebih lanjut menggunakan pengujian DMRT (Duncan's Multiple Range Test).

Prosedur penelitian diawali dengan seleksi benih. Seleksi benih dilakukan dengan memilih benih yang telah masak fisiologis dan berkualitas baik yaitu kulit biji berwarna merah tua, memiliki ukuran dan warna seragam, permukaan kulitnya tidak cacat, bebas dari hama dan penyakit. Setelah didapat benih yang dibutuhkan yaitu 720 benih kopi robusta, dilakukan pengelupasan kulit benih menggunakan cutter, saat penggupasan kulit benih jangan sampai melukai bagian benih. Benih yang telah terkupas di cuci bersih dengan aquades. Pembuatan konsentrasi hormon giberelin dilakukan dengan mengencerkan giberelin pekat menggunakan akuades dengan rumus M1 . V1= M2. V2 (Indrianto, 1990).

Benih kopi robusta direndam selama 30 menit dalam gelas piala yang berisi hormon giberelin yang telah ditentukan yang telah diberi label sesuai dengan konsentrasi yang telah ditentukan yakni 100 ppm, 200 ppm, 300 ppm, dan 400 ppm. Setelah perendaman selama 30 menit dengan hormon giberelin dengan sebelumnya dilakukan perendaman dengan perlakuan suhu air selama 30 menit. Setelah itu diamati pengamatan benih tersebut.

Pengukuran parameter adalah

1. Laju perkecambahan (hari) :

$$
L \text { perk }=\frac{\mathrm{N} 1 \mathrm{~T} 1+\mathrm{N} 2 \mathrm{~T} 2+\ldots \ldots . \mathrm{NxTx}}{\sum \text { benih berkecambah }}
$$

Ket : $\quad \mathrm{N}: \sum$ benih berkecambah satuan waktu $\mathrm{T}$ : Waktu benih berkecambah

2. Kecambah Normal (\%) : Kec Normal $=\frac{\sum \text { benih kecambah normal }}{\sum \text { benih yang diuji }} \times 100 \%$

3. Kecambah Abnormal (\%): Kec Abnormal $=\frac{\sum \text { benih kecambah abnormal }}{\sum \text { benih yang diuj }} \times 100 \%$ $\sum$ benih yang diuji

4. Benih Mati (\%):

Benih Mati $=\frac{\sum \text { benih mati }}{\sum \text { benih yang diuji }} \times 100 \%$

\section{HASIL DAN PEMBAHASAN}

\section{Laju Perkecmbahan (hari)}

Berdasarkan Tabel 1 jenis air memberikan pengaruh yang nyata terhadap laju perkecambahan. Pada table tersebut didapatkan bahwa data laju perkecambahan tercepat terdapat pada perlakuan hormon giberelin dengan konsentrasi 400 ppm dengan air kelapa (G4J3) yakni 25.87 hari dan data laju perkecambahan terlama terdapat pada perlakuan hormon giberelin 300 ppm dengan air mineral suhu $60^{\circ} \mathrm{C}$ (G3J2) yakni 60.00 hari. Pada data laju perkecambahan ini bermaksud untuk melihat waktu kecepatan tumbuh benih kopi berkecambah terhadap pemberian perlakuan hormon giberelin dan jenis air yang berbeda. Kondisi laju 
perkecambahan dengan perlakukan giberelin 400 ppm dengan air kelapa yang diberikan dapat mempercepat perkecambahan benih kopi dari biasanya hal ini menunjukkan bahwa perlakuan yang dilakukan dapat meningkatkan laju perkecambahan benih kopi tersebut.

Tabel 1. Laju Perkecambahan terhadap Beberapa Konsentrasi Giberelin dan Jenis Air

\begin{tabular}{ccccc}
\hline \multirow{2}{*}{ Giberelin } & \multicolumn{3}{c}{ Jenis Air } & \multirow{2}{*}{ Rataan } \\
\cline { 2 - 4 } & $\mathrm{J} 1$ & $\mathrm{~J} 2$ & $\mathrm{~J} 3$ & \\
\hline G1 & 50.48 & 59.49 & 43.48 & 51.15 \\
G2 & 34.77 & 58.47 & 39.63 & 44.29 \\
G3 & 31.23 & 60.00 & 37.36 & 42.86 \\
G4 & 35.00 & 55.08 & 25.87 & 38.65 \\
\hline Rataan & $37.87 \mathrm{~b}$ & $58.26 \mathrm{a}$ & $36.59 \mathrm{~b}$ & \\
\hline
\end{tabular}

Keterangan: Angka-angka yang diikuti oleh huruf yang berbeda menunjukkan pengaruh yang berbeda nyata antar perlakuan menurut DMRT pada taraf $\alpha=5 \%$. J1: akuades; J2: air mineral suhu $60^{\circ} \mathrm{C}$; J3: air kelapa; G1: 100 ppm; G2: 200 ppm; G3: 300 ppm; G4: 400 ppm

Laju perkecambahan merupakan suatu pengamatan untuk menentukan kondisi vigor benih atau kemampuan benih untuk tumbuh per satuan waktu. Semakin cepat benih dapat berkecambah maka semakin baik laju perkecambahan. Laju perkecambahan berkaitan dengan kecepatan tumbuh benih dan kemampuan untuk benih berkecambah normal yang mana apabila benih bisa tumbuh lebih cepat, maka kondisi benih untuk tumbuh menjadi bibit tanaman semakin cepat dengan sumber energi bersal dari endosperm atau cadangan makanan yang tersedia di dalam benih tersebut maupun pemberian dari luar yang berasal dari media perkecambahan dan perlakuan yang diberikan. Laju perkecambahan erat kaitannya dengan kualitas hidup benih diawal dengan cara melihat benih berkecambah dengan waktu yang cepat lalu daya tahan hidup benih tersebut setelah berkecambah. Hal ini didukung oleh Sutopo (1998) menyatakan bahwa daya kecambah benih memberikan kemampuan benih tumbuh normal menjadi tanaman yang wajar dalam keadaan biofisik lapangan yang serba optimum.

\section{Kecambah Normal (\%)}

Berdasarkan Tabel 2 hormon giberelin dan jenis air yang berbeda pada pengamatan kecambah normal menunjukkan bahwa data rataan persentase kecambah normal tertinggi terdapat pada perlakuan hormon giberelin dengan konsentrasi 400 ppm dengan air kelapa (G4J3) yakni sebesar $86.67 \%$ dan data rataan persentase kecambah normal terendah terdapat pada perlakuan hormon giberelin 200 ppm dengan Air Mineral Suhu $60^{\circ} \mathrm{C}$ (G2J2) yakni $50.00 \%$. Pada tabel diatas perlakuan jenis air berpengaruh nyata yang mana rataan data tertinggi terdapat pada perlakuan J3 yakni air kelapa dan rataan data terendah terdapat pada perlakuan $\mathrm{J} 2$ yakni air mineral suhu $60^{\circ} \mathrm{C}$.

Perlakuan J3 berbeda nyata dengan perlakuan J1 dan J2 yang mana perlakuan tersebut berdampak pada perkecambahan benih kopi untuk pengembangan bibit tanaman kopi kedepannya dengan cara mempercepat penyediaan bibit tanaman kopi dengan kondisi kecambah normal yang baik dan pembibitan yang tumbuh seragam sehingga penyediaan bibit yang dibutuhkan untuk keperluan petani kopi bisa tersedia sesuai kebutuhan berdasarkan perluasan areal penanaman kopi yang akan ditingkatkan.

Tabel 2. Kecambah Normal terhadap Beberapa Konsentrasi Giberelin dan Jenis Air

\begin{tabular}{ccccc}
\hline \multirow{2}{*}{ Giberelin } & \multicolumn{3}{c}{ Jenis Air } & Rataan \\
\cline { 2 - 4 } & $\mathrm{J} 1$ & $\mathrm{~J} 2$ & $\mathrm{~J} 3$ & \\
\hline G1 & 73.33 & 58.33 & 76.67 & 69.44 \\
G2 & 75.00 & 50.00 & 80.00 & 68.33 \\
G3 & 75.00 & 71.67 & 83.33 & 76.67 \\
G4 & 85.00 & 73.33 & 86.67 & 81.67 \\
\hline Rataan & $77.08 \mathrm{~b}$ & $63.33 \mathrm{c}$ & $81.67 \mathrm{a}$ &
\end{tabular}

Keterangan: Angka-angka yang diikuti oleh huruf yang berbeda menunjukkan pengaruh yang berbeda nyata antar perlakuan menurut DMRT pada taraf $\alpha=5 \%$. J1: akuades; J2: air mineral suhu $60^{\circ} \mathrm{C}$; J3: air kelapa; G1: 100 ppm; G2: 200 ppm; G3: 300 ppm; G4: 400 ppm.

Perendaman benih juga dipengaruhi oleh lama perendaman dalam air, semakin lama perendaman maka bobot benih akan naik maksimal 2-3 kali bobot awal hal ini sesuai dengan Sumanto \& Wahyuni (1993) yang menyatakan bahwa perlakuan pada benih berdampak pada ketersediaan air dan oksigen, semakin lama biji direndam, maka semakin besar masuknya air pada endosperma biji tersebut, namun ada batasan tertentu untuk melihat lamanya perendaman benih tersebut karena terlalu lama direndam maka biji akan mengalami pembusukan dan rusak. Perlakuan jenis air kelapa memnberikan pengaruh nyata terhadap persentase kecambah normal dibandingkan dengan perlakuan jenis air lainnya yang mana air kelapa tersebut dapat meningkatkan respon perkecambahan benih kopi lebih cepat berkecambah dan tidak merusak benih tersebut dengan kandungan zat pengatur tumbuh yang terdapat pada air kelapa tersebut dibandingkan dengan perlakuan yang lainnya.

Dalam hal ini air kelapa berperan dalam perkecambahan normal yang mana air kelapa mengandung unsur hara dan zat pengatur tumbuh untuk meningkatkan proses perkecambahan normal. Pernyataan ini didukung oleh Mulyani et al., (2018) yang menyatakan bahwa air kelapa muda mengandung zat hara dan zat pengatur tumbuh yang diperlukan untuk perkembangan dan pertumbuhan tanaman.

\section{Kecambah Abnormal (\%)}

Berdasarkan Tabel 3 jenis air memberikan pengaruh nyata terhadap persentase kecambah abnormal. Pada tabel tersebut didapatkan bahwa data rataan kecambah abnormal tertinggi pada perlakuan hormon giberelin 200 ppm dengan air mineral suhu $60^{\circ} \mathrm{C}(\mathrm{G} 2 \mathrm{~J} 2)$ yakni 23.33 $\%$ dan data rataan kecambah abnormal terendah terdapat pada perlakuan hormon giberelin 400 ppm dengan akuades (G4J1) dan hormon giberelin 400 ppm dengan Air Mineral Suhu $60^{\circ} \mathrm{C}$ (G4J3) yakni $0.00 \%$. Pada perlakuan kecambah abnormal untuk melihat kondisi benih abnormal yang digunakan dihubungkan dengan kondisi kadar air benih yang tinggi bisa berdampak pada kondisi benih yang tidak bisa berkecambah atau abnormal walau sudah diberikan perlakuan untuk mendukung perkecambahan dari benih tersebut. Kadar air yang optimal berkisar antar $21-27$ $\%$ yang mana kondisi tersebut di bawah kadar air optimum benih berkecambah dengan baik hal ini sesuai dengan Arif \& Ilahi (2018) yakni kadar air benih yang 
dianggap ideal untuk proses perkecambahan berkisar antara 21 - $23 \%$ karena kadar air yang terlalu rendah tidak akan mengaktifkan enzim yang mendorong perkecambahan, sedangkan kadar air yang lebih tinggi dapat berbahaya bagi kondisi embrio pada benih tersebut yang menyebabkan benih tumbuh abnormal.

Tabel 3. Kecambah Abnormal terhadap Beberapa Konsentrasi Giberelin dan Jenis Air

\begin{tabular}{|c|c|c|c|c|}
\hline \multirow{2}{*}{ Giberelin } & \multicolumn{3}{|c|}{ Jenis Air } & \multirow{2}{*}{ Rataan } \\
\hline & $\mathrm{J} 1$ & $\mathrm{~J} 2$ & J3 & \\
\hline G1 & 1.67 & 8.33 & 3.33 & 4.44 \\
\hline G2 & 5.00 & 23.33 & 1.67 & 10.00 \\
\hline G3 & 5.00 & 13.33 & 3.33 & 7.22 \\
\hline G4 & 0.00 & 13.33 & 0.00 & 4.44 \\
\hline Rataan & $2.92 \mathrm{~b}$ & $14.58 \mathrm{a}$ & $2.08 \mathrm{~b}$ & \\
\hline
\end{tabular}

Keterangan: Angka-angka yang diikuti oleh huruf yang berbeda menunjukkan pengaruh yang berbeda nyata antar perlakuan menurut DMRT pada taraf $\alpha=5 \%$. J1: akuades; J2: air mineral suhu $60^{\circ} \mathrm{C}$; J3: air kelapa; G1: 100 ppm; G2: 200 ppm; G3: 300 ppm; G4: 400 ppm

\section{Benih Mati (\%)}

Berdasarkan Tabel 4 hormon giberelin dan jenis air yang berbeda tidak memberikan pengaruh yang nyata terhadap persentase benih mati. Pada tabel tersebut didapatkan bahwa data rataan tertinggi pada perlakuan hormon giberelin $100 \mathrm{ppm}$ dengan air mineral suhu $60^{\circ} \mathrm{C}$ (G1J2) yakni $33.33 \%$ dan data rataan terendah terdapat pada perlakuan G3J3, G4J2 dan G4J3 yakni $13.33 \%$. Kondisi benih mati merupakan perlakuan yang diterapkan tidak sesuai dengan harapnnya dan perlakuan yang diberikan tersebut berdampak pada perubahan kondisi fisik benih kopi yang menyebabkan benih tersebut tidak berkecambah dan rusak karena efek perlakuan suhu tinggi yang menyebabkan terjadinya kerusakan pada fisik benih kopi, dengan demikian benih tersebut dapat merusak bahan-bahan yang terkandung didalam benih tersebut sehingga benih tidak dapat tumbuh. Oleh kondisi dari benih yang bervigor rendah, dan telah mengalami penurunan integritas membran sebagai hasil dari deteriorasi dari kerusakan mekanik menjadi salah satu pemicu benih mati. Selama imbibisi benih yang memiliki struktur membran lemah melepaskan koloidal sitoplasmik ke medium imbibisi, koloidal dengan sifat elektrolitik membawa sebuah muatan elektrolik yang dapat dideteksi dengan konduktivitas meter (Copeland \& McDonald, 2001).

Tabel 4. Benih Mati terhadap Beberapa Konsentrasi Giberelin dan Jenis Air

\begin{tabular}{ccccc}
\hline \multirow{2}{*}{ Giberelin } & \multicolumn{3}{c}{ Jenis Air } & \multirow{2}{*}{ Rataan } \\
\cline { 2 - 4 } & J1 & J2 & J3 & \\
\hline G1 & 25.00 & 33.33 & 20.00 & 26.11 \\
G2 & 20.00 & 26.67 & 18.33 & 21.67 \\
G3 & 20.00 & 15.00 & 13.33 & 16.11 \\
G4 & 15.00 & 13.33 & 13.33 & 13.89 \\
\hline Rataan & 20.00 & 22.08 & 16.25 & \\
\hline
\end{tabular}

Keterangan: Angka-angka yang diikuti oleh huruf yang berbeda menunjukkan pengaruh yang berbeda nyata antar perlakuan menurut DMRT pada taraf $\alpha=5 \%$. J1: akuades; J2: air mineral suhu $60^{\circ} \mathrm{c}$; J3: air kelapa; G1: 100 ppm; G2: 200 ppm; G3: 300 ppm; G4: 400 ppm

\section{KESIMPULAN}

Perlakuan jenis air memberikan pengaruh yang nyata terhadap parameter laju perkecambahan, persentase kecambah normal dan abnormal. Pada perlakuan jenis air data laju perkecambahan tercepat yakni sebesar 36,59 hari dan kecambah normal tertinggi sebesar $81,67 \%$ pada perlakuan air kelapa (J3). Sedangkan data berpengaruh tidak nyata terdapat pada pengamatan benih mati (\%).

\section{UCAPAN TERIMA KASIH}

Penulis ucapkan kepada BOPTN Universitas Andalas yang telah mendanai kegiatan penelitian ini dengan skim Riset Dosen Pemula (RDP) Tahap 1 Tahun 2021 dengan Nomor Kontrak T/6/UN.16.17/PT.01.03/Pangan-RDP/2021. Sangat bermanfaat bagi peneliti dan untuk pengembangan institusi Universitas Andalas pada umumnya.

\section{DAFTAR PUSTAKA}

Andjarikmawati, D. W., Mudyantini, W., Marsusi. (2005). Perkecambahan dan Pertumbuhan Delima Putih (Punica ganatum L) Dengan Perlakuan Asam Indol Asetat dan asam Giberelat. J. Biosmart 7(2): 91-94.

Arif, M. dan Akbar, I. N. M. (2018). Aplikasi Metode Oven Suhu Tinggi Tetap dan Benih Utuh Dalam Pengujian Kadar Air Benih Kelapa Sawit (Elaeis guineensis Jacq). J. Pen Kelapa Sawit. 26(3) : 153 - 159.

Badan Pusat Statistika (BPS). https://sumbar.bps.go.id.

(2020).

Copeland, L. O. \& M. B. McDonald. (2001). Seed Science and Technology Kluwer Academic Publisher. London.

Hardiyanto. (1995). Pengaruh Gibberelin dan Asam Askorbat Terhadap Perkecambahan dan Pertumbuhan Markisa. J. Hortikultura. 5 (4): 61 - 66.

Lestari, D., R. Linda \& Mukarlina. (2016). Pematahan Dormansi dan Perkacambahan Biji Kopi Arabica (Coffea Arabica L.) dengan Asam Sulfat (H2SO4) dan Giberelin (GA3). Jurnal Protobiont 5(1): 8-13.

Marthen, E. Kaya, \& H. Rehatta. (2013). Pengaruh perlakuan pencelupan dan perendaman terhadap perkecambahan benih sengon (Paraserianthes falcataria L.). Jurnal Agologia. 2 (4): 10--16 p.

Mulyani, C., Syukri, \& Kurniawan, R. (2018). Respon Perkecambahan Benih Kopi (Coffea,sp) Terhadap Skarifikasi dan Perendaman Dalam Air Kelapa. Fakultas Pertanian, Universitas Samudra. Agrosamudra.Jurnal Penelitian.

Najiati, S. \& Danarti. (2012). Kopi, Budidaya dan Penanganan Lepas Panen. Jakarta: PT. Penebar Swadaya.

Netsere, A. \& Kufa, T. (2015). Rivew of Arabica Coffe Nursery Management Reserch In Ethiopia.Journal of Biology, Agriculture and Healthcare.Vol 5(11):20-23.

Rosa, S. D. V. F., McDonald, M. B., Veiga, A. D., Villela, L. \& Fereira, I. A. (2010). Staging Coffee Seedling Growth: a Rationale for Shortenning The Coffee Seed Germination Test. J. Seed Sci \&Technol 38: 421-431.

Rosa, S. D. V. F., Carvalho, A. M., McDonald, M. B., Von Pinho, E. R. V., Silva, A. P.\& Veiga, A. D. (2011). The Effect of Storage Condition on Coffee Seed and Seedling Quality. J.Seed Sci \& Technol 39: 151-164. 
Sumanto \& Sriwahyuni, (1993). Pengembangan

Perlakuan Benih Terhadap Perkecambahan. Pusat

Penelitian dan Pengembangan Tanaman Industri.

Sutopo, L. (1998). Teknologi Benih. PT Raja gafindo. Jakarta. 